TranscUlturAl vol. 1, (4) 2011, 63-75.

http://ejournals.library.ualberta.ca/index.php/TC

\title{
Failures of Domesticity in Contemporary Russian-American Literature: Vapnyar, Krasikov, Ulinich, and Reyn
}

\author{
Karen Ryan \\ University of Virginia
}

In the last decade, the phenomenon of Russian hybrid literature has taken root and flourished. The majority of writers who comprise this group are Russian-American, but also Russian-Canadian, Russian-French, Russian-German, and Russian-Israeli. Most left the Soviet Union (before 1991) or Russia (after 1991) as small children or adolescents; in a few cases they emigrated as young adults. Their Russian cultural background has been spliced with Western education. Many have learned the craft of literature in American MFA programs and they have been publishing prolifically in high-profile venues such as The New Yorker, Harper's Magazine, Atlantic Monthly, and Slate. Several have established a robust Internet presence, publishing fiction and essays on line and reviewing one another's work. Despite some controversy about hybrid literature's relationship to Russian literature, at least three panels were devoted to these writers and their works at the national meeting of the American Association for the Advancement of Slavic Studies in November 2009. ${ }^{1}$

In light of the fact that the cultural and political situation has changed radically in the last twenty years, it is not surprising that the work of Russian hybrid writers is very different from that of émigré writers of the First and Third Waves of the twentieth century. ${ }^{2}$ Russian hybrid writers are neither exiles nor refugees nor expatriates nor émigrés. ${ }^{3}$ Free to travel (actually or imaginatively) between East and West and maintaining contact with their place of birth, they are rather writers of the contemporary Russian diaspora. The language of their fiction is English, German, French, or Hebrew; they write in their second, adopted language, the language acquired in emigration.

1 This organization has since been renamed the Association for Slavic, East European and Eurasian Studies.

2 The First Wave of emigration followed the 1917 Bolshevik Revolution and ensuing Civil War of 1918-1921. The Third Wave was a phenomenon of the 1970s and 1980s, when Soviet emigration policy was relatively lenient.

3 A good adumbration of the nomenclature of exilic literature is provided by Mary McCarthy in her article "A Guide to Exiles, Expatriates, and Internal Emigres." 
TranscUlturAl vol. 1, (4) 2011, 63-75.

http://ejournals.library.ualberta.ca/index.php/TC

Since the fall of the Soviet Union, the borders - for both people and books - are vastly more porous. So drastically has the relationship between homeland and diaspora changed that one might conclude that the very nature of the boundaries has been altered. Unlike émigré literature of the First and Third Waves, Russian hybrid literature does not focus primarily on Russia, nor does it anticipate return. And unlike other literatures of immigration, these works are not chiefly about arrival or assimilation. Reflecting the major cultural shifts occurring in the last twenty years, Russian hybrid literature often dwells on the nature of identity in a post-Soviet, transcultural world. These works concentrate on the cultural journey or crossing; they concern themselves with the translation of the self and they interrogate the meaning of the hyphen in modifiers such as Russian-American. In the continual shifting and redefinition of the center and the margins (Ingram 2), the diaspora sometimes becomes the center. These texts express what Stacey Weber-Fève calls a "diasporic consciousness...that is marked by double or multiple identifications" (xxxiii).

Of particular interest in the definition of transcultural identity in these texts is the notion of gender, i.e. how gender roles are negotiated and reconfigured in adopted homelands. Several writers of Russian hybrid literature consider the translation of gender roles (specifically female roles) into diasporic culture. Among these are Lara Vapnyar, who emigrated from Russia to the United States at the age of 23 and has published two collections of stories (There Are Jews in My House [2003] and Broccoli and Other Tales of Food and Love [2008]) and a novel (Memoirs of a Muse [2006]); Anya Ulinich, who came to the United States at 17 and has written the novel Petropolis (2007); Sana Krasikov, born in Ukraine and brought up in Georgia before emigrating to the United States, where she has published a collection of stories entitled One More Year (2008); and Irina Reyn, who left Moscow with her family when she was seven and is the author of the novel What Happened to Anna K. (2008).

Given that these writers were shaped both by Russian (or Soviet) and Western cultures, it is important to consider their attitudes toward feminism. The pluralization of feminisms in the last few decades allows a recognition of difference that is crucial to an apprehension of these works (Friedman 5). Traditional feminism encourages women writers to claim authentic subjectivity and to reject patriarchal, hegemonic social structures. However, Russian hybrid writers' relationship with feminism is necessarily problematized by the legacy of Marxism, the peculiar Soviet interpretation of feminism, and the domestic "double burden" shouldered by their mothers and grandmothers. Locational feminism - to 
TranscUlturAl vol. 1, (4) 2011, 63-75.

http://ejournals.library.ualberta.ca/index.php/TC

borrow Susan Stanford Freidman's term - pays attention to time and place, taking "as its founding principle the multiplicity of heterogeneous feminist movements and the conditions that produce them" (5). This concept is extremely useful in considering Russian hybrid texts and their treatment of women's roles, femininity, and domesticity. Bringing with them (if only as a distant memory) the baggage of ideologically prescribed equality that in practice frequently made women's lives more difficult, Russian-American women writers examine gender roles through a double filter. Traditional Russian ideas about gender (quite apart from Soviet policies and practice) complicate this dynamic. In short, the characters peopling these texts are often unsettled; they "negotiate multiple and unstable positions" (Lurie 2) in respect to gender identity.

A woman writer who claims transnational status is not only unsettled, but also unsettling. This seems particularly true in the case of Russian writers, for there is a strong tradition of identifying Russian womanhood with the nation itself. Both romantic and oppressive, this convention links woman with home and with community. Home entails restrictions and limitations on the individual's independence and creative freedom (Wiley xvii). A woman who chooses the diaspora (and hence the world) over homeland is uncanny, even dangerous, because she "rejects her role as representation of home/the mother's body to male desire and so is a threat to patriarchy as well as to the state" (Marcus 273). This may explain, to some extent, why Russian hybrid literature has met with such harsh criticism in Russia.

Distance (both temporal and geographical) from the center offers significant creative opportunities, particularly to women writers. Freed from the patriarchal constructs of the homeland, they have a fresh and enriched perspective on the cultures they describe. If women in Russia have often been internal exiles from the hegemonic structures of society, then living in the diaspora allows them to externalize their exile. They may effectively portray the institutions and traditions that shaped them; their focus on Russian cultural and social mores is keener precisely because they are "ex-centric" (Ingram 6), commenting from the margins. The homelessness of the diaspora may thus be extremely productive. ${ }^{4}$ Leaving home seems to catalyze analysis - often wry and ironic - of the oppressive social structures experienced at home. Expectations and prejudices about marriage, children, and other forms

4 Of course, it is possible to reproduce the hegemonic cultural structures of the center in diasporic writing. A good example of this tendency in Russian hybrid literature is the work of Gary Shteyngart: The Russian Debutante's Handbook (2002) and Absurdistan (2006). 
TranscUlturAl vol. 1, (4) 2011, 63-75.

http://ejournals.library.ualberta.ca/index.php/TC

of domesticity are illuminated in the fictional works of these hybrid writers. Having transcended the gender discourse of Russia and/or the Soviet Union, they can rewrite home from the dual, flexible perspective of the voluntary exile.

The set of activities traditionally regarded as "female," the domain of the domestic, is frequently foregrounded by these women writers. In focusing on homemaking, e.g. cooking, cleaning, sewing, they interrogate and refashion gender norms inherited with their Russian cultural background. Writing as they do in a second language in the diaspora, they question the very idea of home (domus), suggesting that it is contested space. Its domestic rituals create "a complex framework for identity and subjectivity construction" (Weber-Fève xiii). Household tasks involve repetition; the patterns of the domestic tend to be circular. This circularity can express continuity of tradition and reinforce identity. However, the shift from center to diaspora encourages "re-cycling" of the domestic. Thus apparent failures of domesticity can point to the productive formation of new identities. Moreover, breaking domestic cycles or reconfiguring them in these narratives sometimes leads to questioning larger structures and institutions. Failures of domesticity described by these writers often suggest the possibility of altering traditional hegemonies in gender roles.

Food preparation is very much a female occupation and it is often imperceptible to men. Reyn makes explicit the gendering of the rituals associated with cooking in describing a gathering of friends, all of whom are Bukharian Jews living in New York. While the men talk, smoke, and listen to music in the living room, the wife (who is never named) prepares food, serves her husband's friends, and clears away dishes. Reyn remarks: "Steam was drifting in from the kitchen, but they ignored its tendrils, it did not exist for them" (What Happened to Anna K. 81). Reyn is sympathetic to the project of preserving Bukharian culture in the disapora, but does not leave its customs unexamined. Tatiana, the narrator of Vapnyar's Memoirs of a Muse, is aware that good girls are expected to cook and clean but rebels against the confinement of that identity. Remembering her experience on a camping trip while still living in the Soviet Union, she contrasts the drudgery of cooking to the exhilaration of sex: "I was not a good girl! I thought, fingering the box of contraception pills in my pocket. I needed a prince who would save me from being a potato-peeling Cinderella and turn me into a Princess/Bad Girl by offering me a cigarette and dragging me into the woods" (44). Although Tatiana rejects the role of preparing food, she presumes that the agent of her identity transformation will be a man who will, moreover, use physical 
TranscUlturAl vol. 1, (4) 2011, 63-75.

http://ejournals.library.ualberta.ca/index.php/TC

force. Vapnyar's narrator is ironically indulgent toward her younger self, gently mocking her refusal to conform to a gender stereotype as naïve and inconsistent. It is the process of questioning the stereotype, the gradual growth toward a new, consciously constructed identity in emigration that interests Vapnyar. This remembered incident is one small breakdown of domesticity that points toward the wholly reconfigured identity her narrator will eventually achieve.

Cooking is consistently connected to marriage and the successful performance of a wife's traditional duties in these texts. Tatiana's grandmother in Memoirs of a Muse recounts Dostoevsky's relationship with his wife Anna Grigorievna, instructively pointing out to Tatiana that her cooking dinner for her husband was a form of submission:

"He gambled away her ring, her earrings, her shawl, and once even her shoes and her dress, so she couldn't even go shopping."

"What was the point in going shopping if he'd already gambled away all the money?"

"Well, maybe she hoped to ask a nice salesman for credit, or just wanted to window-shop....And when he came back, instead of apologizing he yelled at her for not fixing his supper on time!"

"Did she yell back at him?"

"Never! She apologized for not fixing supper. You see, she was a very good wife." (17)

Much later in the novel, when Tatiana is defining her identity as a muse to the American writer Mark Schneider, she claims success in her attempt to prepare and serve him food: "I soon learned to make simple sandwiches that Mark liked as a late-night snack and brew coffee or tea the way he preferred" (130). Ulinich's protagonist Sasha Goldberg, having come to America as a mail-order bride, understands her role to include feeding her fiancé Neal: "Sasha pours grated cheese over a tortilla, folds the tortilla in half, and shoves it in the microwave. Neal likes to have a beer and a quesadilla when he first gets home" (Petropolis 125). It is not important that the meals prepared are basic and require little skill. The domestic acts of cooking and serving are symbolic; female characters in these texts try on the ready-made identity of nurturer offered to them by Russian culture and ultimately refashion it to suit life in the diaspora.

A particularly rich example of the extended use of cooking metaphors is Vapnyar's story "A Bunch of Broccoli on the Third Shelf." Nina has recently emigrated to America with her husband, but he soon leaves her. Nina's love of vegetables sustains her both before and after her husband's departure; her enjoyment of them is sensual, involving sight, smell, 
TranscUlturAl vol. 1, (4) 2011, 63-75.

http://ejournals.library.ualberta.ca/index.php/TC

and touch. Indeed, Nina's (mostly fantasy) experience with vegetables is described by Vapnyar as mildly erotic. She seems to engage much more intimately with vegetables than with her husband, reading a cookbook in bed:

"Her favorite book, Italian Cuisine: The Taste of the Sun, included step-by-step photographs of the cooking process. In the photos, smooth light-skinned female hands with evenly trimmed fingernails performed all the magical actions on the vegetables. They looked like Nina's hands, and Nina fantasized that they were hers. It was she, Nina, who made those perfect curled carrot slices. It was she who pushed the hard, stubborn stuffing into the bell peppers, or rinsed grit off lettuce leaves, or chopped broccoli florets, scattering tiny green crumbs all over the table. Nina's lips moved, forming the rich, passionate words of the cooking instructions: "Brush with olive oil," "bring to a boil and simmer gently," “serve hot," “scoop out the pulp," “chop,” “slice," “crush," “squash.” When eventually she put the book away, cuddled against her husband's back, and closed her eyes, her lips continued moving for some time. (Broccoli 13-14)

Vapnyar is playful with this device, saturating her text with cooking metaphors to the point of self-parody. Her description of fennel is unmistakably phallic: "It had a funny, slightly ribbed surface, and it was heavy and spouted weird green shoots that seemed to grow out of nowhere" (Broccoli 19). Vapnyar's connection of cooking with marriage is pervasive and ironic. Nina's failure of domesticity moves her toward a new identity reconfigured in diasporic culture. It is significant that the story ends with her enjoying the (actual, not imagined) smell of broccoli steaming on the stove. In the first place, the broccoli is being prepared by a man (a reversal of gender stereotype); secondly, broccoli is a decidedly Western vegetable.

Like food preparation, housecleaning is a domestic activity traditionally defined as women's work. Female hybrid writers explore the presumption that women take pride in keeping a tidy home. Reyn notes in passing that Bukharian culture preserves the expectation that women will not only prepare food, but clean up after the men who consume it: "In the kitchen, Lev scooped out a bowl of plov, slathered a cube of butter across the top, and ate it just like that, standing up in the living room, leaning against the wall, ignoring the stray, tumbling grains of rice his mother would have to sweep up later" (What Happened to Anna K. 53). Vapnyar is similarly ironic in describing Tatiana's anxiety about her cleaning prowess in Memoirs of a Muse: "What if he hates the way I clean? Didn't my aunt always scrunch her face when she picked up a plate just washed by me? Didn't my mother always remark that 'wetting and washing floors were two different things'?" (127). Tatiana's insecurities are fed, 
TranscUlturAl vol. 1, (4) 2011, 63-75.

http://ejournals.library.ualberta.ca/index.php/TC

significantly, by remembered criticisms of her cleaning by her Russian female elders. As it happens, her mother will encourage her to establish her own identity, get an education, and become independent. The critical voices that she hears at this early stage in the novel are those of Russian cultural tradition, not entirely relevant to life in the diaspora. The most explicit critique of the stereotype of Russian women who enjoy housework is provided by Ulinich in her novel Petropolis. Her heroine Sasha tells her Russian friend about her American fiancé's dull-wittedness on this account:

"Neal harbors many strange notions. Last night, we get back from Bridal Barn, and he begins to complain that the bathroom is dirty. All right, I say, I'll take care of it. Then he goes and shows me my Kupid's Korner profile [her personal ad], which says that I love to clean. Sometimes I look at Neal, and he appears normal enough, and I wonder, how can he believe this obinea? Who the fuck loves to clean?” (122-23)

Sasha's failure of domesticity is a clear statement of independence from the oppressive notion of Russian female subservience exploited by the Moscow mail-order bride company.

Vapnyar's story "Salad Olivier" is a study of conflict between inherited expectations about gender roles and the more open possibilities offered by diasporic culture. The story is a first-person account by the narrator Tanya of her family's experience as Russian immigrants settling into life in New York. Tanya's parents are disappointed by the absence of appropriate (i.e. Russian) suitors; her mother nags her incessantly about her single status. Vapnyar recounts a psychologist's diagnosis of her father's depression: “He yearns to be relieved, but in a subtle, not humiliating way. It usually works better if he is relieved by a male child, but sometimes it helps when a daughter marries, thus finding a man who will figuratively replace her father" (Broccoli 77). The diagnosis effectively parodies sexist assumptions about gender made in traditional Russian culture; a hypothetical male child would do a better job at relieving the father's guilt, but a female child can help by getting married. Eventually, Tanya meets a man acceptable to her parents and he becomes part of their family circle. Her parents welcome Vadiim warmly, but Tanya is wary of the oppressive domesticity the relationship entails. Returning home to Vadim and her parents sitting around the kitchen table cutting up ingredients for Salad Olivier (a standard of Russian cuisine), Tanya remarks: "I don't know why seeing Vadim's shoes in the corner make me recoil" (Broccoli 83). She fleetingly considers leaving, rationalizing that "The mechanism is working. They don't need me. I am free to go" (Broccoli 84). Standing outside in the street, 
TranscUlturAl vol. 1, (4) 2011, 63-75.

http://ejournals.library.ualberta.ca/index.php/TC

contemplating liberation from the expectations imposed by her Russian background, she experiences nostalgia and dislocation. Understanding that she is indeed an integral part of her family and that she is needed - "if only as a link holding them together" (Broccoli 84) she goes inside and joins them in making Salad Olivier. It is significant that she enters the kitchen, a key site of female domesticity, and picks up an egg; while she is clearly ambivalent, she seems determined to reconcile her role as nurturer and (potential) mother with her new identity in the diaspora.

Rejection of traditional Russian definitions of women's gender roles may signal successful renegotiation of identity in emigration. On the basis of these texts by female Russian hybrid writers, it seems that failures of domesticity indicate growth, development, and - in some cases - the configuration of transnational identity. For these writers, domesticity is closely connected with home and with domestication. This cluster of concepts involves limitation; as Rachel Bowlby writes, "domestication represents a deprivation of full human potential, and domestication is associated with a false version of femininity" (87). Domesticity implies a sacrifice or sublimation of one's true self, whereas failures of domesticity suggest the realization or formation of a fuller, more complete self.

In her story "Lydia's Grove," Vapnyar describes an editor, a colleague of the narrator's mother, who serves them delicious food from a deli when they come to visit. She doesn't bother to cook, considering it a waste of time. It is only when she takes a lesbian lover that she is consigned to the kitchen, forced into a domestic role that is clearly constricting: "She stood at the sink now, wearing a stained flowery apron, cleaning dishes or peeling potatoes" (There Are Jews In My House 75). For the narrator of "Lydia's Grove," their friend's eschewal of cooking expressed her true nature and allowed her intellect wider scope. Vapnyar's story "Luda and Milena" recounts the competition between two elderly Russian women for the attentions of a man against the backdrop of an ESL class in Brooklyn. Luda and Milena try to out-cook one another, making tenderer and juicier meatballs to win Aron's affection. When he chokes on a meatball and dies at an ESL picnic, the women declare a truce and admit their true feelings:

It was cold and very bright outside. Milena reached into her bag for her sunglasses, but Luda only squinted her eyes.

"Going down that way?” Milena asked. Luda nodded. They started walking down the street together.

"You know," Luda said, after a while, "I don't enjoy cooking that much."

"Me neither," Milena said, and they continued to walk." (Broccoli 113) 
TranscUlturAl vol. 1, (4) 2011, 63-75.

http://ejournals.library.ualberta.ca/index.php/TC

In the story "Mistress," Vapnyar contrasts Misha's grandmother, who cooks ceaselessly, to Elena Pavlovna, who prefers store-bought to homemade. Misha's grandfather has taken to visiting Elena Pavlovna after meeting her in an ESL class, and for both Misha and his grandfather, she is an intriguing woman. Reflecting on the grandmother's domestic exertions, Vapnyar writes: “[Misha] couldn't understand why she put so much work into the preparation of this food, which was consumed in twenty minutes, in silence, and didn't even taste good" (There Are Jews In My House 101). Tea at Elena Pavlovna's apartment, on the other hand, is accompanied by gracious conversation; Misha is reminded of characters speaking in Chekhov plays. It is Elena Pavlovna who gives Misha's grandfather the desire to learn English and to engage in life anew in his new surroundings.

For female characters living in penury in the West and supporting their families back home, domesticity may be read even more darkly, as servitude. Performance of domestic tasks may reinforce female characters' identity as immigrants rather than as Russian women. Vapnyar's story "Borscht" describes a woman who has come to the United States to support her husband and two daughters, left behind in Russia. Alla works as a nanny in Manhattan and supplements her income by working as a prostitute. Sergey, a Russian man working in New York to provide for his wife back in Russia, solicits Alla's services out of loneliness, but their sexual encounter is unsuccessful. She offers to feed him instead, serving him a steaming, colorful bowl of borscht. Alla is thus doubly cast in the role of domestic servant, as sexual object and cook. She expresses bitterness that her family seems to value the income she provides more than her presence: "Oh, I know, I know. I know this song by heart. 'Don't worry, Mom, we manage fine here.' And they do, they do manage fine without me, as long as the money's coming" (There Are Jews In My House 45-46). Sasha Goldberg, the protagonist of Ulinich's Petropolis, makes her way in America by cleaning; she cleans for the family in Chicago who takes her in after she flees from her fiancé Neal, and she later establishes a small cleaning business in New York. She keenly feels her servitude while living with the Tarakans. Her status is actually worse than that of the paid housecleaners, for she receives only food and shelter and is kept a virtual prisoner in the house.

"Every Sunday, Mrs. Tarakan handed Nina and Esmerelda a stack of twenties and two plastic containers of leftover Sabbath food. Sasha was never paid. She told herself this was logical, since the Tarakans fed her and gave her a roof over her head. In the confines of the Waterfall House, she had no use for money." (176)

This work is licensed under a Creative Commons Attribution 3.0 License 
TranscUlturAl vol. 1, (4) 2011, 63-75.

http://ejournals.library.ualberta.ca/index.php/TC

Sasha embodies the female immigrant's quandary, painfully choosing to be away from her daughter in order to provide a better life for her. In Sana Krasikov's story "Maia in Yonkers," the recently widowed Maia has left her adolescent son in Tblisi to work as a caretaker for an elderly woman in New York. She misses her son dreadfully, but is hurt and angry when he visits and demands that she buy him things she cannot afford. Krasikov is unflinching in training her narrative lens on Maia's separation from her son Gogi; by characterizing him as rude and disrespectful, she conveys the mother's dilemma powerfully. She sketches the political situation in Georgia in enough detail to demonstrate that Maia's choice is agonizing: to be with her son or to provide a decent standard of living for him. These writers consider the social and economic motivations leading women to live and work in the diaspora apart from their children. They are largely sympathetic to their characters, who bear loneliness and guilt as associated costs.

Russian hybrid literature explores the complicated relationship between center and margin, and metaphors of domesticity contribute to this narrative project. The very idea of Russia as a home to which one might return is no longer viable in the contemporary period. The Soviet Union no longer exists, so that home of these writers' youth is only remembered. Ulinich's Sasha Goldberg expresses the anxiety of homelessness eloquently:

"How am I supposed to raise a kid if I live split in two, one half at a time? As long as Mama and Nadia live there, Asbestos 2 is still a place I can go return to. Sometimes, when I visit there, it feels like the only real place I know. Soon, it will all be contained within me, slowly disappearing... But what am I? Homo Post-Sovieticus? Homo Nowhere?" (311)

Although Sasha resists the notion of living in the world rather than a town, Ulinich as author ultimately concurs that the concept of home is unstable. Russia, like the traditional center of other diasporic literatures, can no longer be regarded "un-problematically as a geographical location or source of identity, memory, and the personal" (Weber-Fève, xxii).

Home as remembered by these female hybrid writers tends to be constructed as confining and restrictive. This is not to say that they express no nostalgia; there is indeed a sense of loss, but the nostalgia is for childhood, a time out of time rather than for Soviet culture. Escape from the tyranny of home is actually critical for the process of transnational identity formation recounted by these writers. Their texts interrogate inherited assumptions about gender and suggest that the "deeply-imbedded cultural scripts that defined women in terms of familial and domestic roles" (Rubenstein 2) associated with home are oppressive. 
TranscUlturAl vol. 1, (4) 2011, 63-75.

http://ejournals.library.ualberta.ca/index.php/TC

Their female characters - who all share some of their authors' features - enact failures of domesticity by way of claiming independence in the new world of the diaspora. It is significant that many of these narratives describe a heroine who reconfigures her identity as a writer or artist. The narrator of Vapnyar's Memoirs of a Muse, for example, becomes a writer herself, having realized that serving as a muse to a bad writer is a waste of her energy and talent. Ulinich's Sasha Goldberg rediscovers her artistic skill in emigration and the novel ends with her teaching art in New York. Leaving home and rejecting the gender roles prescribed by traditional Russian culture are, it seems, preconditions for finding one's voice. Failures of domesticity paradoxically represent successful steps in these émigré bildungsromane toward redefinition of the self. 
TranscUlturAl vol. 1, (4) 2011, 63-75.

http://ejournals.library.ualberta.ca/index.php/TC

\section{REFERENCES}

Bowlby, Rachel. "Domestication." Feminism Beside Itself. Ed. Diane Elam and Robyn Wiegman. New York: Routledge, 1995. 71-91. Print.

Friedman, Susan Stanford. Mappings. Feminism and the Cultural Geographies of Encounter. Princeton: Princeton University Press, 1998. Print.

Ingram, Angela. "Introduction. On the Contrary, Outside of It." Women's Writing in Exile. Ed. Mary Lynn Broe and Angela Ingram. Chapel Hill: University of North Carolina Press, 1989. 1-15. Print.

Krasikov, Sana. One More Year. New York: Spiegel and Grau, 2008. Print.

Lurie, Susan. Unsettled Subjects. Restoring Feminist Politics to Poststructuralist Critique. Durham: Duke University Press, 1997. Print.

McCarthy, Mary. "A Guide to Exiles, Expatriates, and Inner Emigrés." Altogether Elsewhere. Writers on Exile. Ed. Marc Robinson. San Diego: Harcourt Brace, 1994. 49-58. Print. Marcus, Jane. "Alibis and Legends. The Ethics of Elsewhereness, Gender and Estrangement." Women's Writing in Exile. Ed. Mary Lynn Broe and Angela Ingram. Chapel Hill: University of North Carolina Press, 1989. 269-294. Print.

Reyn, Irina. What Happened to Anna K. New York: Simon and Schuster, 2008. Print.

Rubenstein, Roberta. Home Matters: Longing and Belonging, Nostalgia and Mourning in Women's Fiction. New York: Palgrave, 2001. Print.

Shteyngart, Gary. Absurdistan. New York: Random House, 2006. Print.

Shteyngart, Gary. The Russian Debutante's Handbook. New York: Penguin, 2002. Print.

Ulinich, Anya. Petropolis. New York: Viking, 2007. Print.

Vapnyar, Lara. Broccoli and Other Tales of Food and Love. New York: Pantheon, 2008. Print.

Vapnyar, Lara. Memoirs of a Muse. New York: Random House, 2006. Print.

Vapnyar, Lara. There Are Jews In My House. New York: Random House, 2003. Print.

Weber-Fève, Stacey. Re-bybridizing Transnational Domesticity and Femininity. Women's Contemporary Filmmaking and Lifewriting in France, Algeria, and Tunisia. Lanham, England: Rowman and Littlefield, 2010. Print. 
TranscUlturAl vol. 1, (4) 2011, 63-75.

http://ejournals.library.ualberta.ca/index.php/TC

Wiley, Catherine. "Introduction." Homemaking. Women Writers and the Politics and Poetics of Home. Ed. Catherine Wiley and Fiona R. Barnes. New York: Garland, 1996. xv-xxvi. Print. 